\title{
ANALISA FAKTOR-FAKTOR YANG BERPENGARUH TERHADAP PARTISIPASI PRIA DALAM KELUARGA BERENCANA DI WILAYAH KERJA UPT PUSKESMAS IBRAHIM ADJIE KOTA BANDUNG TAHUN 2018
}

\author{
Sri Hennyati A \\ Program Studi Diploma Tiga Kebidanan STIkes Dharma Husada \\ srihennyati@gmail.com
}

\begin{abstract}
ABSTRAK
Indonesia merupakan negara terluas dengan jumlah penduduk terbanyak di atara 10 negara anggota ASEAN. Berdasar atas data Badan Informasi Geospasial (BIG) tahun 2012 dan data penduduk sasaran program pembangunan kesehatan tahun2011-2014, luas negara Indonesia sebesar 1,922,570 $\mathrm{km}^{2}$ dengan jumlah populasi sebanyak $244,775,797$ orang. Jumlah kepadatan penduduk per $\mathrm{km}^{2}$ sebesar 128 orang. Program KB nasional merupakan salah satu program untuk meningkatkan kualitas penduduk, mutu sumber daya manusia, kesehatan dan kesejahteraan sosial, yang selama ini dilaksanakan melalui pengaturan kelahiran, pendewasaan usia kawin, peningkatan ketahanan keluarga dan kesejahteraan keluarga. penetlitian ini bertujuan untuk mengetahui faktor-faktor yang berpengaruh terhadap partisipasi pria dalam keleuarga berencana di Puskesmas Ibrahim Adjie Kota Bandung. Jenis penelitian ini adalah observasional dengan metode penelitian survey analitik yaitu survey penelitian yang mencoba menggali bagaimana dan mengapa fenomena kesehatan itu terjadi. Persentase responden dengan umur pria <31 tahun $(65,7 \%)$ lebih banyak daripada responden dengan umur pria $>31$ tahun $(34,2 \%)$. Sebagian besar responden dengan jumlah anak $<3(57,1 \%)$ daripada jumlah anak $>3(42,0 \%)$. Pendidikan responden diperoleh persentase bahwa sebagian besar responden mempunyai jenjang pendidikan lanjut $(100,0 \%)$ daripada pendidikan dasar $(0,0 \%)$, sebagian besar pendapatan responden $<\mathrm{Rp}$. $400000(65,7 \%)$.

Ada hubungan yang bermakna antara pengetahuan terhadap KB dengan Partisipasi pria dalam Keluarga Berencana $(\mathrm{p}$ value $=0.0001)$

Ada hubungan yang bermakna antara sosial budaya terhadap KB dengan Partisipasi pria dalam Keluarga Berencana ( $\mathrm{p}$ value $=0.024)$.
\end{abstract}

Kata Kunci: Partisipasi pria dalam KB

\section{PENDAHULUAN}

Indonesia merupakan negara terluas dengan jumlah penduduk terbanyak di atara 10 negara anggota ASEAN. Berdasar atas data Badan Informasi Geospasial (BIG) tahun 2012 dan data penduduk sasaran program pembangunan kesehatan tahun2011-2014, luas negara Indonesia sebesar 1,922,570 $\mathrm{km}^{2}$ dengan jumlah populasi sebanyak $244,775,797$ orang. Jumlah kepadatan penduduk per $\mathrm{km}^{2}$ sebesar 128 orang. ${ }^{1}$
Hasil sensus Badan Pusat Statistik (BPS) pada bulan Agustus 2010, jumlah penduduk Indonesia adalah 237,556,363 orang terdiri atas $119,507,600$ laki dan $118,048,783$ perempuan dengan laju pertumbuhan penduduk $1,49 \%$ per tahun. Upaya mengatasi masalah tersebut salah satunya, yaitu dengan adanya program keluarga berencana (KB). Program KB yang baru didalam paradigma ini misinya sangat menekan pentingnya upaya menghormati hak-hak reproduksi sebagai integral dalam 
meningkatkan kualitas keluarga. ${ }^{2}$ Keluarga berencana (KB) merupakan program pemerintah untuk membatasi jumlah dengan mencegah kehamilan, kelahiran yang dapat menunda kehamilan.

Pada awalnya pendekatan keluarga berencana lebih diarahkan pada aspek demografi dengan upaya pokok pengendalian jumlah penduduk dan penurunan fertilitas (TFR). Program KB nasional merupakan salah satu program untuk meningkatkan kualitas penduduk, mutu sumber daya manusia, kesehatan dan kesejahteraan sosial, yang selama ini dilaksanakan melalui pengaturan kelahiran, pendewasaan usia kawin, peningkatan ketahanan keluarga dan kesejahteraan keluarga. Konferensi Internasional tentang Kependudukan dan Pembangunan (ICPD 1994) menyepakati perubahan paradigma, dari pendekatan pengendalian populasi dan penurunan fertilitas, menjadi lebih kearah pendekatan kesehatan reproduksi dengan memperhatikan hak-hak reproduksi dan kesetaraan gender. ${ }^{3}$

Memasuki era baru program KB di Indonesia diperlukan adanya reorientasi dan reposisi program secara menyeluruh dan terpadu. Reorientasi dimaksud terutama ditempuh dengan jalan menjamin kualitas pelayanan keluarga berencana dan kesehatan reproduksi yang lebih baik serta menghargai dan melindungi hak-hak reproduksi yang menjadi bagian integral dari hak-hak azasi manusia yang bersifat universal. Prinsip pokok dalam mewujudkan keberhasilan program KB dimaksudkan adalah peningkatan kualitas disegala bentuk serta kesetaraan dan keadilan gender melalui pemberdayaan perempuan serta peningkatan partisipasi pria. ${ }^{3}$

Meskipun pemerintah Indonesia telah mulai melaksanakan pembangunan yang berorientasi pada kesetaraan dan keadilan gender, namun demikian, masalah utama yang kita hadapi saat ini adalah rendahnya partisipasi laki dalam pelaksanaan program KB dan Kesehatan Reproduksi. ${ }^{3}$

Menurut penelitian sri widya menyatakan partisipasi pria/suami dalam KB adalah tanggung jawab pria/suami dalam kesertaan ber KB, serta berperilaku seksual yang sehat dan aman bagi dirinya, pasangan dan keluarganya. Bentuk partisipasi pria/suami dalam KB dapat dilakukan secara langsung dan tidak langsung. Partisipasi pria/suami secara langsung (sebagai peserta KB) adalah pria/suami menggunakan salah satu cara atau metode pencegahan kehamilan, seperti kondom, vasektomi (kontap pria), serta KB alamiah yang melibatkan pria/suami (metode sanggama terputus dan metode pantang berkala). ${ }^{4}$

Partisipasi laki baik dalam praktek KB maupun dalam pemeliharaan kesehatan ibu dan anak termasuk pencegahan kematian maternal hingga saat ini masih rendah. Untuk menurunkan angka kematian ibu (AKI), diperlukan gerakan nasional yang juga melibatkan semua pihak dengan program dan kegiatan yang komprehensif, terkait terukur dan seimbang yang pada akhirnya peran pria/suami dalam program $\mathrm{KB}$ akan mampu mendorong peningkatan kualitas pelayanan $\mathrm{KB}$, peningkatan 
kesetaraan dan keadilan gender, peningkatan penghargaan terhadap hak asasi manusia, dan berpengaruh positif dalam mempercepat penurunan angka kelahiran total (TFR), penurunan angka kematian ibu, dan penurunan angka kematian bayi (AKB). ${ }^{5}$

Angka parisipasi pria dalam penggunaan alat kontrasepsi di Indonesia masih sangat rendah yatitu hanya 2,1\% peserta KB pria dan mereka umumnya memakai kondom. Persentase tersebut lebih rendah jika dibandingkan dengan negara lain seperti Iran 12\%, Tsuisia 16\%, Malaysia 9-11\%, bahkan di Amerika Serikat mencapai $32 \%$. Sanagt sedikit pria yang mau menggunakan alat kontrasepsi baik kondom maupun vasektomi, dari total jumlah akseptor KB di Indonesia sekitar 97\% adalah perempuan, oleh sebab itu sosialisasi program $\mathrm{Kb}$ dikalangan pria harus ditingkatkan. ${ }^{1}$

Menurut penelitian Hesti, Handayani menyatakan hambatan keluarga atau istri juga menjadi penghalang perkembangan partisipasi pria terutama di perdesaan, sedangkan diperkotaanan seperti DKI tidak menjadi masalah. Sekitar $70 \%$ menurut penuturan suami di DIY bahwa istri karena mencari nafkah merasa kwatir suami menyeleweng, takut pada efek samping terutama penurunan libido. ${ }^{6}$

Hasil studi pendahuluan yang dilakukan di puskesmas Ibrahim Adjie tahun 2018 jumlah akseptor KB pada pria masih sangat rendah. ${ }^{7}$

Melihat adanya angka partisiapsi pria dalam KB sangat rendah, maka penulis berminat untuk melakukan penelitian " Analisis Faktor-faktor yang berpengaruhi terhadap psrtisipasi pria dalam keluarga berencana di Puskesmas Ibrahim Adjie Kota Bandung Tahun 2018”.

penetlitian ini bertujuan untuk mengetahui faktor-faktor yang berpengaruh terhadap partisipasi pria dalam keleuarga berencana di Puskesmas Ibrahim Adjie Kota Bandung.

\section{METODE PENELITIAN}

Jenis penelitian ini observasional dengan metode penelitian survey analitik yaitu survey penelitian yang mencoba menggali bagaimana dan mengapa fenomena kesehatan itu terjadi. Kemudian melakukan analisis dinamika korelasi antara fenomena baik antara faktor risiko dengan faktor efek antara faktor risiko maupun antar faktor efek.

Populasi terjangkau dalam penelitian ini adalah semua pria pasangan usia subur yang berkunjung dan melakukan KB di UPT Puskesmas Ibrahim Adjie Kota Bandung.

Pengambilan sampel menggunakan teknik total Sampling. Sample diambil keseluruhan objek yang diteliti dan dianggap mewakili seluruh populasi ini. Teknik yang digunakan untuk pengambilan sample adalah seluruh pria pasangan usia subuh yang berkunjung ke UPT Puskesmas Ibrahim Adjie.

Pemilihan sampel memenuhi kriteria inklusi, yaitu Pria pasangan usia subur dan Pria/suami yang menggunakan alat kontrasepsi. Sedangkan kriterian eksklusi adalah pria/ suami yang tidak bersedia dijadikan responden. 
Variabel terikat dalam penelitian adalah partisipasi pria dalam keluarga berencana, variabel bebas adalah umur, jumlah anak, pendidikan, pendapatam, pengetahuan terhadap KB, sosial budaya terhadap KB. Instrumen yang digunakan untuk mengumpulkan data adalah kuesioner terstruktur berupa pertanyaan terbuka untuk identitas responden.

Pengumpulan data dilakukan dari rekomendasi UPT Puskesmas Ibrahim Adjie meliputi keterangan lokasi, jumlah Pria PUS, dan data pendukung lainnya.

Penelitian dilakukan dengan memberikan kuesioner awal kepada responden yang terpilih untuk diisi dan ditunggui oleh peneliti. Kueisoner dikembalikan lagi dan untuk dilakukan mengolahan data oleh peneliti. ${ }^{21}$

Analisa data dilakukan secara univariat dan bivariat. Analisis univariat menggunakan statistik deskriptif untuk melihat frekuensi dan distribusi variabel bebas, variabel terikat. Tabel frekuensi digunakan untuk menggambarkan proporsi karakteristik subjek penelitian dengan melakukan pengkategorian variabel yang dianalisis.

Analisis bivariat untuk mengetahui hubungan dua variabel berdasarkan tabel $2 \times 2$ pada tingkat kepercayaan 0,05 dan Confidence Interval $95 \%(\alpha=0.05)$.

Penelitian dilakukan di wilayah kerja UPT Puskesmas Ibrahim Adjie. Dilaksanakan dari bulan Desember 2018 sampai bulan Januari 2019.

\section{HASIL}

\section{Analisis Univariat}

Tabel 1 Distribusi frekuensi responden berdasarkan umur, jumlah anak. Pendidikan, Pendapatan di Puskesmas Ibrahim adjie Kota Bandung

\begin{tabular}{|c|c|c|}
\hline Karakteristik & $\mathbf{f}$ & $\%$ \\
\hline \multicolumn{3}{|l|}{ Umur pria } \\
\hline$<31$ tahun & 22 & 65,7 \\
\hline$>31$ Tahun & 13 & 34,2 \\
\hline Total & 35 & 100,0 \\
\hline \multicolumn{3}{|l|}{ Jumlah anak } \\
\hline Jumlah anak $<3$ & 15 & 42,8 \\
\hline Jumlah anak $>3$ & 20 & 57,1 \\
\hline Total & 35 & 100,0 \\
\hline \multicolumn{3}{|l|}{ Pendidikan } \\
\hline Pendidikan dasar & 0 & 0 \\
\hline Pendidikan lanjutan & 35 & 100 \\
\hline Total & 35 & 100,0 \\
\hline \multicolumn{3}{|l|}{ Pendapatan } \\
\hline < Rp. 4.000 .000 & 23 & 65,7 \\
\hline$>$ RP. 4.000 .000 & 12 & 34,3 \\
\hline Total & 35 & 100,0 \\
\hline \multicolumn{3}{|l|}{ Pengetahuan } \\
\hline Baik & 9 & 25,7 \\
\hline Cukup & 11 & 31,4 \\
\hline Kurang & 15 & 42,9 \\
\hline Total & 35 & 100,0 \\
\hline \multicolumn{3}{|l|}{ Sosial budaya } \\
\hline Tidak mendukung & 22 & 62,9 \\
\hline mendukung & 13 & 37,1 \\
\hline Total & 35 & 100,0 \\
\hline
\end{tabular}

Berdasarkan tabel 1, presentase responden dengan umur pria > 31 tahun $(65,7 \%)$ lebih banyak daripada responden dengan umur pria > 31 tahun $(34,2 \%)$. Sebagian besar responden dengan jumlah anak $<3(42,8 \%)$ daripada jumlah anak > 3 $(57,1 \%)$. Semua responden mempunyai jenjang pendidikan lanjutan (100\%) dan sebagian pendapatan responden $<\mathrm{Rp}$ 4.000.000. Pengetahuan responden sebahagian berpengetahuan kurang $(42,9 \%)$, responden sebagian besar budaya responden tidak mendukung terhadap KB $(62,9 \%)$. 
Tabel 2 Distribusi frekuensi Partisipasi pria dalam Keluarga Berencanan di UPT Puskesmas Ibrahim Adjie Kota Bandung

\begin{tabular}{l|c|c}
\hline \multicolumn{1}{c|}{ Karakteristik } & f & \% \\
\hline Partisipasi pria dalam KB & & \\
Tidak menggunakan alkon & 27 & 57,4 \\
Menggunakan alkon & 8 & 17,0 \\
\hline Total & 35 & 100,0 \\
\hline
\end{tabular}

Berdasar atas tabel 2 terlihat bahwa sebagian besar responden tidak menggunakan alat kontrasepsi $(57,4 \%)$ dari pada yang menggunakan alat kontribusi $(17,0 \%)$.

\section{Analisis Bivariat}

Tabel 3 Distribusi frekuensi Hubungan Pengetahuan terhadap KB dengan Partisipasi Pria dalam Keluarga Berencana di UPT Puskesmas Ibrahim Adjie Kota Bandung.

\begin{tabular}{|c|c|c|}
\hline \multicolumn{3}{|c|}{ Partisipasi pria dalam KB } \\
\hline Pengetahuan & $\begin{array}{c}\text { Tidak } \\
\text { Menggunakan } \\
\text { alat kontrasespsi }\end{array}$ & $\begin{array}{l}\text { Menggunakan } \\
\text { alat kontrasepsi }\end{array}$ \\
\hline Baik & 5 & 4 \\
\hline$\%$ & $1,4 \%$ & $11,4 \%$ \\
\hline Cukup & 6 & 5 \\
\hline$\%$ & $17,1 \%$ & $1,4 \%$ \\
\hline Kurang & 10 & 5 \\
\hline$\%$ & $28,5 \%$ & $1,4 \%$ \\
\hline
\end{tabular}

Berdasarkan tabel 3, responden yang tidak menggunakan alat kontrasepsi proposi pengetahuan kurang $(28,5 \%)$, pada responden yang menggunakan alat kontrasepsi proposi pengetahuan baik $(11,4 \%)$. Umtuk mengetahui adanyahubugan antara pengetahuan teradap KB dengan partisipasi pria dalam keluarga berencana maka dapat dianalisis dengan menggunakan Uji Chi-Square diperoleh nilai $\mathrm{p}=0,0001 \quad(\mathrm{p}<0,005) \quad$ yang berarti ada berhubungan yang bermakna antara pengetahuan terhadap KB dengan partisipasi pria dalam keluarga berencana.

Tabel 4 Distribusi frekwensi Hubungan social budaya terhadap KB dengan Partisipasi pria dalam keluarga berencana di UPT Puskesmas Ibrahim Adjie Kota Bandung.

\begin{tabular}{|c|c|c|c|}
\hline \multicolumn{4}{|c|}{ Partisipasi pria dalam KB } \\
\hline $\begin{array}{c}\text { Sosial } \\
\text { budaya }\end{array}$ & $\begin{array}{c}\text { Tidak } \\
\text { menggunakan } \\
\text { alat } \\
\text { kontrasepsi } \\
\end{array}$ & $\begin{array}{c}\text { Menggunakan } \\
\text { alat } \\
\text { kontrasepsi }\end{array}$ & Total \\
\hline $\begin{array}{c}\text { Tidak } \\
\text { mendukung }\end{array}$ & 14 & 8 & 22 \\
\hline$\%$ & $40,0 \%$ & $22,0 \%$ & $62 \%$ \\
\hline Mendukung & 6 & 7 & 13 \\
\hline$\%$ & $17,0 \%$ & $21,0 \%$ & $38 \%$ \\
\hline
\end{tabular}

Berdasarkan tabel 4 , responden yang tidak menggunakan alat kontrasepsi proporsi budaya yang tidak mendukung (40,0\%) lebih besar daripada dengan budaya yang mendukung $(17,0 \%)$. Pada responden yang Total mengunakan alat kontrasepsi proporsi budaya yang mendukung (21.0\%) lebih pesar daripada budaya yang tidak mendukung (22,0\%). Untuk mengetahui adønya hubungan antara Sosial Budaya terhadap KB dengan Partisipasi Pria dalam Keluarga Berencana, maka dapat dianalisis dengan menggunakan uji Chi-Square test diperoleh nilai $\mathrm{p}$ value sebesar 0.024 ( $\mathrm{p}$ <0.05) yang berarti ada hubungan yang bermakna antara Sosial Budaya terhadap KB dengan Partisipasi Pria dalam Keluarga Berencana.

\section{PEMBAHASAN}

Pendidikan merupakan upaya untuk memberikan pengetahuan sehingga terjadi perubahan perilaku positif yang meningkat. 
Tingkat pengetahuan menunjukan korelasi dengan terjadinya perubahan perilaku positif yang meningkat dengan demikain pengetahuan juga meningkat. Pendidikan merupakan tingkat dasar pengetahuan yang dimiliki seseorang. Hasil penelitian yang menunujukan rendahnya keikutsertaan suami dalam hal Pendidikan suami, dikarenakan Pendidikan suami tidak secara langsung dengan pengetahuan. Pengetahuan merupakan aspek kognitif pada diri manusia, sebelum menjadi suatu kegiatan yang sifatnya motorik pengetahuan akan mempengaruhi sisi afektif atau sikap pada diri manusia ${ }^{23}$. Pendidikan yang tinggi belum tentu penegtahuannya akan tinggi pula, akibatnya keikutsertaan suami dalam ber KB juga belum tentu baik hasilnya sebagaimana kondisi Pendidikan, suami. Bila ditinjau dari segi pendidikan menurut hasil analisis lanjut SDKI 2012, ternyata pendidikan berpengaruh negatif terhadap mereka yang berpendidikan tinggi cenderung memilih kondom. ${ }^{4}$

Keluarga berencana (KB) adalah cara merencanakan keluarga, kapan ingin mendapatkan anak dan berapa jumlah anak. Bila memutuskan untuk menunggu untuk mendapatkan keturunan, maka bias memilih beberapa cara untuk menunda kehamilan dengan kontrasepsi. Hubungan antara jumlah anak dengan keikutsertaan suami dalam KB memiliki hubungan yang erat karena dalam program KB itu sendiri jumlah anak merupakan salah satu tujuan dalam program $\mathrm{KB}^{3}$

Pernyataan tersebut sama dengan penelitian Purwoko (2000) pengetahuan menyumbangkan peran dalam menentukan pengambilan keputusan untuk memilih alat kontrasepsi tertentu. Semakin tinggi tingkat pengetahuan tentang alat kontrasepsi, maka makin meningkat pula perannya sebagai pengambil keputusan. ${ }^{9}$ Hasil penelitian yang sama oleh Wijayanti (2004) melalui wawancara mendalam dan observasi dapat diketahui bahwa ketidaktahuan atau kurangnya pengetahuan masyarakat tentang MOP/vasektomi inilah yang merupakan faktor utama penyebab mereka tidak memilih MOP ini sebagai kontrasepsi pilihan. ${ }^{11}$ Penggunaan alat kontrasepsi merupakan bentuk perilaku seseorang yang didasari penilaian positif pada kegiatan tersebut, baik dengan tujuan tertentu maupun sekedar mengikuti lingkungannya. Hal tersebut menekankan pentingnya sebuah niat dan pemikiran yang positif terhadap perilaku seseorang. Fishben dan Ajzein menyebutkan bahwa keyakinan akibat perilaku merupakan pengetahuan yang berasal dari diri sendiri yang positif maupun negatif. Dari hal tersebut akan menghasilkan sikap yang selanjutnya akan menumbuhkan minat seseorang untuk melakukan perilaku tertentu. ${ }^{9}$

Kajian analisis ini penting karena dengan sebuah pemahaman yang benar akan pengetahuan tentang penggunaan alat kontrasepsi pria dan sikap terhadap KB yang lebih positif akan mendukung keterlibatan pria dalam penggunaan alat kontrasepsi. 


\section{SIMPULAN}

1. Persentase responden dengan umur pria $<31$ tahun $(65,7 \%)$ lebih banyak daripada responden dengan umur pria $>31$ tahun (34,2\%). Sebagian besar responden dengan jumlah anak <3 $(57,1 \%)$ daripada jumlah anak $>3$ (42,0\%). Pendidikan responden diperoleh persentase bahwa sebagian besar responden mempunyai jenjang pendidikan lanjut $(100,0 \%)$ daripada pendidikan dasar $(0,0 \%)$, sebagian besar pendapatan responden < Rp. 400000 $(65,7 \%)$.

2. Ada hubungan yang bermakna antara pengetahuan terhadap KB dengan Partisipasi pria dalam Keluarga Berencana $(\mathrm{p}$ value $=0.0001)$

3. Ada hubungan yang bermakna antara sosial budaya terhadap KB dengan Partisipasi pria dalam Keluarga Berencana $(\mathrm{p}$ value $=0.024)$.

\section{SARAN}

1. Perlunya peningkatan KIE melalui paguyuban atau kelompok KB pria tentang alat kontrasepsi pria yaitu kondom untuk meningkatkan pengetahuan pria tentang alat kontrasepsi kondom.

2. Perlunya bantuan biaya pelayanan $\mathrm{KB}$ dan penyelenggaraan safari $\mathrm{KB}$ selain alat kontrasepsi vasektomi/MOP.

3. Perlunya meningkatkan akses pelayanan KB dengan penyediaan tempat pelayanan KB yang dekat dengan tempat tinggal masyarakat khususnya masyarakat kecamatan Selo.

4. Perlunya dilakukan penelitian lanjut tentang faktor-faktor apa saja yang mempengaruhi partisipasi pria dengan melihat side provider/pemberi pelayanan

\section{DAFTAR PUSTAKA}

1. Ernawati S. Faktor yang memengaruhi keluarga berencana $(\mathrm{KB})$ pria dengan paritisipasi pria dalam keluarga berencana di Wilayah Kerja Puskesmas Sedayu II. J Nurs dan kebidanan Indonesia. 2016;4(2):109.

2. Astuty LWT. Faktor-faktor yang mempengaruhi partisipasi suami dalam menggunakan alat kontrasepsi. J Vokasi Kesehatan. 2016;2(1):24-8.

3. Sri Maya Bhakti. Analisis faktor-faktor yang berpengaruh terhadap partisipasi pria dalam keluarga berencana di kecamatan selo kabupaten boyolali.J Kes Masy. 2017;1(1):7-9.

4. Sulistiawati P. Analisis faktor-faktor yang berpengaruh terhadap partisipasi pria dalam keluarga berencana di kecamatan selo kabupaten Boyolali. J Kes Masy. 2016;7(2):34-43.

5. Budisantoso S I. Faktor-faktor yang berhubungan dengan di Kecamatan Jetis Kabupaten Bantul Tahun 2008. J Promosi

Kesehatan. 2008;11(2):100-109.

6. Maharyani HW, Handayani S. Hubungan karakteristik suami dengan keikutsertaan suami menjadi akseptor keluarga berencana di Wilayah Desa Karangduwur Kecamatan Petanahan Kabupaten Kebumen Jawa Tengah. J Public Heal. 2014;4(1):49-58.

7. Adjie puskesmas ibrahim. data puskemas. 2017.

8. Undang-undang RI. undang-undang Reprublik Indonesia NO 10 tahun 1992 tentang perkembangan kependudukan dan pembangunan keluarga sejahtera. http://birohukumsiskum.sumutprov.go.i d/myadmin/10\%20tahun\%201992.pdf. 1992.

9. BKKBN. Peran pria melalui program $\mathrm{KB}$ dalam kesehatan maternal. gema partisipasi pria. Jakarta; 2000.

10. BKKBN. Pedoman kebijakan teknis keluarga berencana dan kesehatan reproduksi. BKKBN. Jakarta; 2001. 
11. Djamhoer dkk. Bunga Rampai Obstetri dan Ginekologi Sosial. Yayasan Bina Pustaka Sarwono Prawiroharjo. Jakarta; 2005

12. BKKBN. Rapat Kerja Program KB Nasional Jawa Tengah tahun 2008: Kebijakan dan Strategi Operasional Pencapaian Sasaran tahun 2008- 2009. Jawa tengah; 2008.

13. Manuaba. Ilmu Kebidanan, Penyakit Kandungan, \& Keluarga Berencana untuk Pendidikan Bidan. EGC. Jakarta; 2010.

14. Endang. Buku Sumber Keluarga Berencana, Kesehatan Reproduksi, Gender, dan Pembangunan Kependudukan. BKKBN \& UNFPA, editor. Jakarta; 2002.

15. BKKBN. Peningkatan Partisipasi Pria dalam KB \& KR. BKKBN, editor. jakarta; 2005.

16. Syaifudin. Buku Panduan Praktis Pelayanan Kontrasepsi. Yayasan bina pustaka sarwono prawiroharjo, editor. Jakarta; 2003.
17. Wiknjosastro. Ilmu Kebidanan. Yayasan bina pustaka sarwono prawirohardjo, editor. Jakarta; 1999.

18. Bertrand. Kerangka Pikir Konseptual Permintaan KB serta Dampak Pada Fertilitas. Dalam: BKKBN. Peningkatan Akses dan Kualitas Pelayanan KB. BKKBN. Bandung; 2007.

19. BKKBN. pengayoman media keluarga berencana. BKKBN. Jakarta; 1993.

20. Ni Putu Dewi Sri Wahyuni NS, K PM. J urnal Magister Kedokteran Keluarga J urnal Magister Kedokteran Keluarga. J Magister Kedokt Kel. 2013;1(1):80-91.

21. Notoatmodjo S. Metodologi Penelitian Kesehatan. Rineka cipta. Jakarta; 2022.

22. Neolaka. Metode Penelitian dan Statistik. Bandung: Rosda; 2014.

23. Lestari eka rahayu puji. faktor yang mempengaruhi pemilihan metode kontrasepsi mantap pria di kecamatan kapas kabupaten Bojonegoro tahun 2014. j kebid. 2014; 